\section{RANCANG BANGUN SSPD (THE SYSTEM OF SOLAR-POWERED DRIER) UNTUK PENINGKATAN PRODUKSI USAHA IKAN ASIN KERUPUK DESA KUALA GEULUMPANG}

Wan Alamsyah', Asmadi Suria', Rachmad Almi Putra2*

1)Program Studi Teknik Sipil, Fakultas Teknik, Universitas Samudra 2)Program Studi Fisika, Fakultas Teknik, Universitas Samudra

\section{Article history}

Received : 11-06-2018

Revised : 07-05-2019

Accepted: 16-05-2019

\section{*Corresponding author}

Rachmad Almi Putra

Email : rachmad.almi@unsam.ac.id

\begin{abstract}
Abstraksi
Kegiatan pengabdian ini bertujuan untuk merancang alat pengering ikan untuk membantu permasalahan proses pengeringan di waktu hujan, perbaikan kemasan dan perluasan pasar. Kegiatan ini dilakukan selama bulan september sampai oktober 2018 dengan bekerja sama dengan KUB Ratama. Hasil yang dicapai adalah perancangan alat yang diberi nama The System Solar Powered Drier, yang memiliki kapasitas 216 liter dan suhu 5070 derajat celcius, dan telah dibangun jaringan pasar dengan toserba Arsala. kegiatan. Keberadaan alat SSPD untuk mesin pengering ikan asin kerupuk, tidak memberikan peningkatan produksi yang signifikan karena kapasitas mesin sangatlah kecil. Perbaikan kemasan mampu meningkatkan pemasaran di wilayah sekitar, yaitu Aceh timur dan kota langsa.
\end{abstract}

Kata Kunci : Mesin Pengering Ikan, Pemasaran, SPPD

\begin{abstract}
This service activity aims to design fish dryers to help with the problems of the drying process in the rain, packaging repairs, and market expansion. This activity is conducted from September to October 2018 in collaboration with Ratama KUB. The results achieved were the design of a device called The Solar Powered Drier System, which has a capacity of 216 liters and a temperature of 50-70 degrees Celsius, and a market network has built with Arsala department store. Activities. The existence of SSPD equipment for cracker salted fish drying machines, does not provide a significant increase in production because the engine capacity is tiny. Packaging repairs can improve marketing in the surrounding area, namely East Aceh and the city of Langsa.
\end{abstract}

Keywords: Fish Drying Machine, Marketing, SPPD

\section{PENDAHULUAN}

Gampong Kuala Geulumpang merupakan sebuah desa yang terletak di kecamatan Julok Kabupaten Aceh Timur Provinsi Aceh. Di desa tersebut terdapat beragam kegiatan ekonomi yang digeluti oleh masyarakat desa tersebut, diantaranya terdapat beberapa kelompok usaha ekonomi masyarakat didominasi oleh kelompok pengolahan ikan kering kerupuk yang merupakan komoditi unggulan dari desa tersebut, disamping itu terdapat juga usahausaha lainnya. Hal ini disebabkan oleh letak geografis desa tersebut yang berdekatan dengan laut. Komoditi ikan kering kerupuk ini merupakan salah satu produk olahan ikan kerupuk yang dilakukan dengan cara penyiangan/ pembersihan isi perut dan pemotongan bagian tubuh ikan dan penjemuran hingga kering dengan memanfaatkan terik sinar matahari langsung. Namun usaha pengolahan ini menemui kendala apabila cuaca tidak mendukung (hujan), sehingga terjadi keterlambatan proses pengeringan yang berdampak langsung terhadap kualitas hasil olahan sehingga mempengaruhi mutu dan rasa.

Ikan yang terkena air hujan dan tidak kering biasanya akan disimpan dalam kotak penyimpanan yang sudah diletakan batu es, umumnya hanya bertahan selama 2 (dua) hari dan sehingga apabila tidak dapat sinar panas matahari/ tidak kering juga maka ikan hasil tangkapan tersebut akan dibuang. Hal ini disebabkan kadar air dapat mempengaruhi karakteristik dari bahan seperti tekstur dan cita rasa pada bahan pangan. Kadar air tinggi dapat meningkatkan kegiatan fisiologi dan enzimatik serta mudah menyebabkan tumbuh dan berkembang biaknya jamur. Pengeringan yang digunakan 
kelompok usaha tersebut masih menggunakan pengeringan manual dengan matahari langsung sehingga kebersihan dan tingkat higienis dari produk yang dikeringkan tidak dapat terjamin, serta lama pengeringan juga sangat mempengaruhi dari ikan yang dihasilkan (Gambar 1). Pengurangan kadar air pada ikan kering kerupuk ini sangat tergantung pada proses pengeringan yang dilakukan, dengan melakukan beberapa studi, proses pengeringan ikan ini dipelajari dan diinovasi dari pengeringan tradisional menjadi pengeringan yang lebih modern sehingga masyarakat dapat menggunakannya dan efektif untuk usaha dan bisnis ikan kerupuk ini sehingga diharapkan dapat menjawab kendala yang dihadapi selama ini.

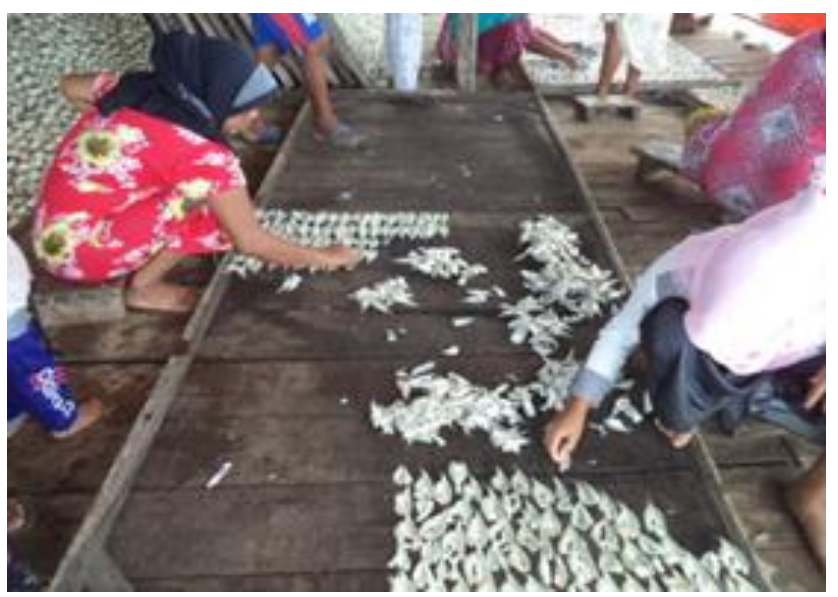

Gambar 1. Proses Penjemuran.

Salah satu inovasi pengeringan ikan yang banyak dikembangkan adalah dengan memanfaatkan tenaga surya (Bintang, Pongoh, \& Onibala, 2013; Handoyo, Kristanto, \& Alwi, 2011; Mukkun, 2016). Metode ini memanfaatkan energi matahari baik secara langsung maupun tidak langsung melalui penyimpanan solar cell. Alat ini mampu melakukan pengeringan tanpa dipengaruhi oleh hujan, kotoran dan juga ikan yang dikeringkan dapat diterima tepat pada waktunya.

Kegiatan pengabdian ini bertujuan merancang alat pengering ikan dengan memanfaatkan energi matahari. Pengaplikasian alat ini diharapkan mampu meningkatkan kesejahteraan masyarakat pesisir pantai dengan produk yang didesain sedemikian rupa agar dihasilkan ikan kering yang bermutu dan higienis untuk dikonsumsi, mengurangi ketergantungan pada cuaca, menekan kerugian yang dialami pada saat panen raya, memperkecil kemungkinan kerusakan yang diakibatkan pembusukan, dan mempercepat proses dan tidak memerlukan lahan yang luas.

\section{METODE PELAKSANAAN}

Penetapan metode dalam pelaksanaan kegiatan didasarkan pada permasalahan prioritas kelompok mitra (Fajrin, Nurmi, \& Harahap, 2018). Pada umumnya, mitra memiliki permasalahan antara lain yaitu :

1. Produksi terhambat jika tidak ada sinar matahari.

2. Mengalami kerugian jika Ikan yang setengah kering harus dibuang jika tidak dijemur lebih dari dua hari

3. Bahan Baku berlimpah namun perputaran di pasar berkurang, sehingga terjadi penumpukan.

4. Keterbatasan Pasar, dan

5. Sistem penjualan yang konvensional, sehingga ada kemungkinan diberi label merek dagang usaha lain

Berdasarkan permasalahan mitra maka dalam pelaksanaan pengabdian dilakukan beberapa tahapan. Tahap perencanaan dan persiapan antara lain melakukan kerjasama dengan mitra dalam merancang program dalam rangka mengatasi persoalan mitra yang ada. Pada tahapan pelaksanaan antara lain menciptakan TTG berupa mesin pengering tenaga surya untuk mengatasi proses produksi ikan asin yang bergantung pada alam, pelatihan manajemen dan strategi pasar serta sosialisasi cara-cara meningkatkan pasar.

\section{PEMBAHASAN}

Kegiatan pengabdian kepada masyarakat oleh Tim Universitas Samudra telah dimulai dari tahap survey lokasi, sosialisasi, monitoring, dan evaluasi. Tahapan ini telah berlangsung dari september hingga oktober 2018.

Pada tahap survey tim berdiskusi dengan ketua kelompok usaha bersama ikan asin kerupuk ratana terhadap permasalahan yang ada pada kelompok tersebut, sehingga tim memperoleh suatu permasalahan dalam kelompok KUB Ratana, Adapun masalah tersebut meliputi proses produksi yang terbatas ketika tidak adanya sinar matahari, dan angka kerugian meningkat saat bahan baku melimpah, namun produksi menurun diakibatkan oleh cuaca yang tidak cerah dan keterbatasan pasar. Adapun solusi yang ditawarkan dan telah disepakati bersama antara tim Pengabdian Kepada Masyarakat dan KUB Ratana adalah Menciptakan TTG berupa mesin pengering tenaga surya (Hanafri, Emawan, Kustanti, Rahayu, \& Perairan, 2016) untuk mengatasi proses produksi ikan asin yang bergantung pada alam, Manajemen dan Strategi pemasaran, Perluasan Pasar. 
Untuk menjawab kebutuhan KUB Ratana, Tim mulai merancang suatu alat yang diberi nama SSPD (solar system the powered dried) dimana alat ini memiliki kapasitas 216 liter yang dilengkapi dua tingkatan rak yang berdimensi $60 \times 60 \mathrm{~cm}$ yang dilingkupi jaring fiber yang kuat dan elastis, untuk menjaga keutuhan dari ikan asin kerupuk. Suhu yang dicapai oleh SSPD ini adalah 50 hingga 70 o C dan suhu tersebut merupakan suhu efektif yang dapat digunakan sebagai pengering ikan tanpa merusak kualitas ikan (Daryanto \& Suprapto, 2014).

Setelah alat tersebut berhasil diciptakan oleh Tim PKM Universitas Samudra, langkah selanjutnya adalah melakukan sosialisasi dan uji coba alat dengan mitra. Sosialisasi ini bertujuan untuk memperkenalkan alat pengeringan tenaga surya dan tata cara pengoperasian alat tersebut (Gambar 2). Pemanfaatan produk ini diharapkan mampu mempercepat proses pengeringan ikan terutama pada saat musim hujan.

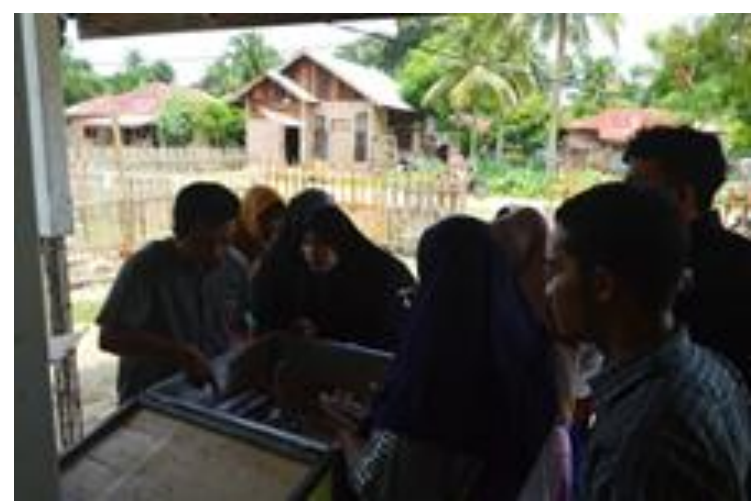

Gambar 2. Arahan Petunjuk Penggunaan Alat SSPD

Selain pemanfaatan alat pengering, langkah selanjutnya adalah melakukan pelatihan pengemasan produk ikan asin sehingga lebih menarik konsumen. Pada pelatihan ini dilakukan pengarahan langkah-langkah pengemasan yang baik, pemberian merek serta inovasi rasa ikan asin kerupuk. Pada pelatihan ini dilakukan pengemasan produk ikan asin kerupuk dalam kemasan, yang terdiri dari 2 rasa original dan Sambalado. (Gambar 3).

Setelah pengemasan selesai tim mulai memasarkan ikan asin kerupuk di supermarket kedai Arsala. Tim juga melakukan monitoring dan evaluasi terhadap proses produksi dan pemasaran.

Keberadaan alat SSPD untuk mesin pengering ikan asin kerupuk, memberikan efek terhadap produksi ikan asin, namun tidak memberikan peningkatan produksi yang signifikan, hal ini disebabkan kapasitas mesin sangatlah kecil, namun di segi pemasaran terjadinya peningkatan pasar di wilayah sekitar, yaitu Aceh timur dan kota langsa, hingga saat ini permintaan pasar terhadap ikan asin kerupuk masih sanggup dipenuhi oleh KUB Ratana.

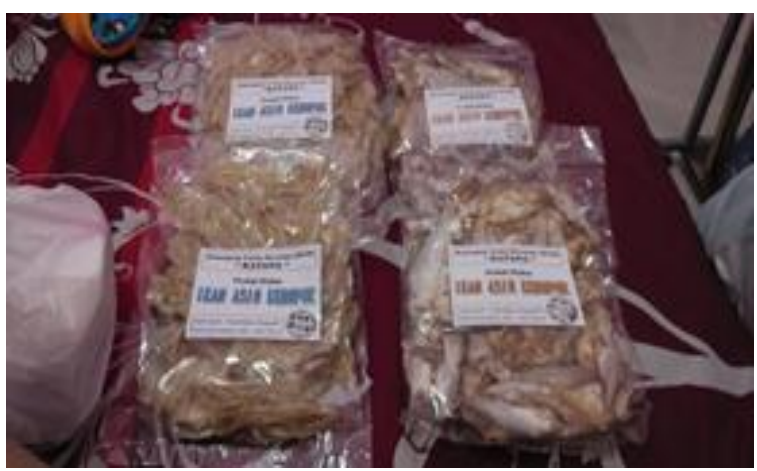

Gambar 4: Ikan asin yang sudah dikemas

\section{KESIMPULAN}

Kegiatan pengabdian ini berhasil membuat Alat SSPD (the Solar System Powered Dried) sebagai alat pengering ikan asin kerupuk pada kelompok usaha bersama Ratana, dan melakukan pelatihan pengemasan ikan asin kerupuk yang lebih menarik, praktis dan ekonomis untuk dipasarkan serta telah dibangun kerjasama dengan kedai Arsala untuk meningkatkan pemasaran ikan asin kerupuk KUB Ratana. Pemanfaatan alat SPPD mampu meningkatkan produksi walaupun tidak signifikan. Perbaikan kemasan produk dapat meningkatkan pemasaran di wilayah sekitar, yaitu Aceh timur dan kota langsa

\section{UCAPAN TERIMA KASIH}

Terima kasih kepada Masyarakat Kuala Geulumpang yang telah menyambut tim PKM Unsam dalam melaksanakan Pengabdian Kepada Masyarakat yang didanai Oleh DIPA Unsam No Kontrak : 697/UN54.6/PM/2018.

\section{DAFTAR PUSTAKA}

Bintang, Y. M., Pongoh, J., \& Onibala, H. 2013. Konstruksi dan Kapasitas Alat Pengering Ikan Tenaga Surya Sistem Bongkar-Pasang. Jurnal Media Teknologi Hasil Perikanan, 1 (2), 40-43.

Daryanto, E., \& Suprapto. 2014. Kaji eksperimental alat pengering tenaga surya dengan variasi sudut konsentrator cermin datar dan sudut riblets untuk pelat absorber. Wikrama Parahita: Jurnal Pengabdian Masyarakat, 15(2), 90-105.

Fajin, M., Nurmi, A., \& Harahap, N. 2018. Pendampingan Kelompok Ternak Dalam Pembuatan Mineral Blok Herbal di Desa Merenu Kecamatan Aek Nabar Barumun Kabupaten Padang Lawas. Martabe: 
Alamsyah, Suria, dan Putra, Wikrama Parahita: Jurnal Pengabdian Masyarakat 2019, Volume 3 Nomor 1: 1-4 DOI: http://dx.doi.org/10.30656/jpmwp.v3i1.837

Jurnal Pengabdian Kepada Masyarakat, 1 (2), 31-35.

Hanafri, M. I., Emawan, A. H., Kustanti, E., Rahayu, E. L., \& Perairan, P. S. T. H. 2016. Pembuatan Prototipe Alat Solar Dryer Berbasis Tenaga Surya Hybrid Sistem Portable. PKMT, 3(4), 1-11.

Handoyo, E. A., Kristanto, P., \& Alwi, S. 2011. Desain dan Pengujian Sistem Pengering Ikan Bertenaga Surya.

Mukkun, Y. 2016. Pembuatan Alat Pengering Ikan Ramah Lingkungan Dengan Menggunakan Panel Surya. Jurnal IImiah FLASH, 2(2), 47-58. 